\title{
Rantai Nilai Cabai di Kawasan Lereng Gunung Merapi Daerah Istimewa Yogyakarta
}

\author{
Value Chain of Chili on the Slopes of Mount Merapi Yogyakarta Province \\ Agus Dwi Nugroho*, Imade Yoga Prasada, Saraswati Kirana Putri, \\ Herdiana Anggrasari, Pinjung Nawang Sari \\ Departemen Sosial Ekonomi Pertanian, Fakultas Pertanian, Universitas Gadjah Mada, \\ Jl. Flora, Bulaksumur, Yogyakarta 55281, Indonesia \\ *Penulis korespondensi: Agus Dwi Nugroho, E-mail: agus.dwi.n@mail.ugm.ac.id
}

Tanggal submisi: 26 Agustus 2017; Tanggal penerimaan: 20 Maret 2020

\begin{abstract}
ABSTRAK
Fluktuasi ketersediaan dan harga cabai disebabkan rantai nilai yang kurang baik. Penelitian ini bermaksud mengetahui mekanisme aliran produk, aliran keuangan serta aliran informasi serta strategi pengembangan untuk mengatasi masalah pada rantai nilai cabai rawit di Kawasan Lereng Gunung Merapi. Penelitian ini dilakukan di Kecamatan Pakem Kabupaten Sleman pada bulan Mei sampai Agustus 2017. Metode random sampling digunakan untuk menentukan responden petani dalam penelitian ini sedangkan sampel pedagang dipilih menggunakan metode snowball sampling. Analisis yang digunakan dalam penelitian ini adalah deskriptif dan SWOT. Hasil penelitian menunjukkan saluran pemasaran paling efisien saat petani menjual cabai kepada konsumen melalui pedagang pengecer. Secara keseluruhan, aliran rantai nilai komoditas cabai di Lereng Gunung Merapi termasuk dalam kategori lancar. Namun begitu, masih terdapat beberapa masalah diantaranya kemampuan budidaya petani masih rendah, fluktuasi produksi dan harga cabai. Untuk mengatasi masalah yang ada diperlukan penyuluhan dan pelatihan budidaya cabai yang intensif dari dinas, penanganan pasca panen di tingkat petani secara profesional dan memperkuat pasar lelang cabai di Kabupaten Sleman.
\end{abstract}

Kata kunci: Cabai; lereng gunung merapi; rantai nilai

\begin{abstract}
Fluctuation of the availability and prices of chili happen because the poor of the value chains. This research intended to know the mechanism related to the product, financial and information flow and development strategy to solve the problem of the chili's value chain on the slopes of Mount Merapi. This research was conducted in Pakem District, Sleman Regency from May-August 2017. The method to determine the farmer respondents is random sampling while the merchants chosen by snowball sampling. The research used descriptive and SWOT analysis. The results showed that the most efficient marketing channels when farmers sell chili to the consumers through the retailers. Overall, the chili's value chain included in the current category. Unfortunately, there are still some problems such as weak of the farmer cultivation ability and fluctuation of production and price. To solve this problem, the local government need make intensive counseling and training of chili cultivation, post-harvest handling in a professional and strengthen the auction market in Sleman Regency.
\end{abstract}

Keywords: Chili; the slopes of mount merapi; value chain 


\section{PENDAHULUAN}

Harga cabai nasional selama periode 2016-2017 tidak stabil dengan melihat koefisien keragaman (KK) masih tinggi yaitu sebesar $29,54 \%$ untuk cabai merah dan 45,62\% untuk cabai rawit (Kementerian Perdagangan, 2017). Fluktuasi harga cabai berdampak negatif kepada produsen maupun konsumen. Pada saat harga turun, maka produsen akan rugi sedangkan saat harga naik maka daya beli konsumen akan turun. Fluktuasi stok dan harga barang sebenarnya disebabkan manajemen rantai nilai yang kurang baik (Tubagus dkk., 2016). Rantai nilai menggambarkan hubungan dan koordinasi para pelaku bisnis dari masuknya bahan mentah, proses produksi primer, pemasaran sampai dapat dikonsumsi (Rofaida, 2012; Kaplinsky, 2013).

Pengelolaan rantai nilai yang baik mampu meminimalkan biaya dan waktu dengan efektif dan efisien sehingga meningkatkan nilai tambah komoditas bagi pelanggan dan keuntungan bagi produsen tanpa mengurangi kualitas produk (Baihaqi dkk., 2014; Mangifera, 2015; Kumar and Rajeev, 2016). Rantai pasok yang baik ditandai dengan terciptanya kolaborasi dan koordinasi dari pelaku usaha hulu sampai hilir (Timisela dkk., 2014).

Fakta di lapangan menunjukkan bahwa salah satu kesulitan mengatur supply chain cabai adalah rantai pemasaran yang cukup panjang sehingga terdapat selisih harga cukup jauh antara produsen dengan konsumen. Hasil penelitian Istiyanti (2010) menunjukkan pemasaran cabai merah keriting di DIY, terutama Kecamatan Ngemplak, petani memperoleh bagian hasil yang lebih rendah daripada pedagang pengecer. Hal tersebut juga diperkuat oleh Rum (2011) yang melakukan penelitian tentang pemasaran cabai besar di Kabupaten Malang. Hasil penelitian menunjukan selisih harga antara produsen dengan konsumen mencapai Rp1.800 dengan keuntungan terbesar diperoleh pedagang pengecer.
Tsurayya dan Kartika (2015) melakukan penelitian mengenai rantai pasok cabai di Kabupaten Garut. Hasil penelitian menunjukkan petani tidak mempunyai informasi pasar yang baik serta tidak memiliki manajemen kelembagaan yang kuat sehingga pedagang akan menggunakan kekuatannya untuk menekan harga di tingkat petani serendah mungkin.

Dengan begitu, maka perlu disusun strategi untuk meningkatkan efektivitas rantai nilai cabai. Langkah ini perlu dilakukan untuk menghindari fluktuasi ketersediaan dan harga cabai serta meningkatkan posisi tawar petani, terutama di sentra produksi komoditas tersebut. Salah satu sentra produksi cabai adalah di kawasan Gunung Merapi yang merupakan wilayah subur namun belum pernah dilakukan penelitian mengenai kondisi rantai nilai komoditas cabai. Penelitian ini bermaksud mengetahui mekanisme aliran produk, aliran keuangan serta aliran informasi serta strategi pengembangan untuk mengatasi masalah pada rantai nilai cabai rawit di Kawasan Lereng Gunung Merapi DIY.

\section{METODE PENELITIAN}

\section{Lokasi dan Waktu Penelitian}

Penelitian ini dilakukan di Kecamatan Pakem Kabupaten Sleman Daerah Istimewa Yogyakarta. Pemilihan lokasi penelitian ini dilakukan secara sengaja (purposive sampling) karena Kecamatan Pakem merupakan wilayah dengan produksi cabai tertinggi di wilayah lereng Merapi. Penelitian dilaksanakan pada bulan Mei-Agustus 2017.

\section{Metode Pengumpulan Data}

Sumber data dalam penelitian ini terdiri dari dua sumber yaitu: 1) Data primer dari wawancara dan diskusi dengan informan terkait rantai nilai cabai, dan 2) Data sekunder yang bersumber dari instansi terkait.

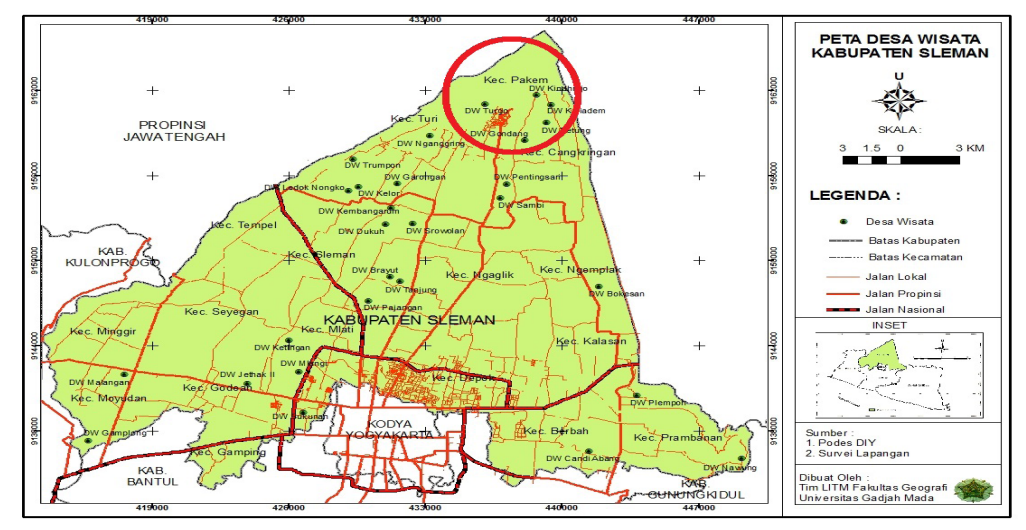

Gambar 1. Peta wilayah penelitian

Sumber: LITM Fakultas Geografi Universitas Gadjah Mada (2015) 
Metode random sampling digunakan untuk menentukan responden petani dalam penelitian ini yaitu anggota kelompok tani Ngudi Rejeki dan kelompok Tani Ngemput yang merupakan kelompok penghasil cabai tertinggi di Kecamatan Pakem. Dari 120 petani yang aktif dalam kegiatan kelompok, ada 30 orang petani yang kemudian menjadi responden dalam penelitian ini. Selanjutnya, dari wawancara dengan petani, maka akan diperoleh informasi mengenai seluruh pedagang yang membeli cabai produksi petani (snowball sampling). Adapun jumlah seluruh pedagang yang membeli cabai petani ada 13 orang.

\section{Metode Analisis}

Untuk mengidentifikasi aktivitas rantai nilai dilakukan dengan analisis deskriptif untuk aliran produk, keuangan, dan informasi.

\section{Analisis deskriptif}

Aliran produk dianalisis dengan menggunakan analisis deskriptif. Langkah pertama yang dilakukan adalah mengidentifkasi pelaku usaha. Selanjtunya, pelaku usaha tersebut disusun urutannya dalam mendistribusikan cabai dari produsen ke konsumen (saluran pemasaran).

\section{Analisis keuangan}

Analisis aliran keuangan yakni dengan mengidentifikasi marjjn pemasaran yang mencoba mengaitkan biaya, pendapatan dan nilai tambah dari komoditas cabai di tiap pelaku usaha (Sipayung, 2010). Untuk menghitung marjin dari setiap lembaga pemasaran digunakan rumus pada Persamaan 1 (Widiastuti dan Harisudin, 2013).

$$
M p=P_{r}-P_{f} \text { atau } M p=B_{p}-K_{p}
$$

Keterangan:

$\mathrm{Mp}=$ Marjin pemasaran $(\mathrm{Rp} / \mathrm{kg})$

$\mathrm{Pr}=$ Harga di tingkat konsumen $(\mathrm{Rp} / \mathrm{kg})$

$\mathrm{Pf}=$ Harga di tingkat produsen $(\mathrm{Rp} / \mathrm{kg})$

$\mathrm{Bp}=$ Biaya pemasaran $(\mathrm{Rp} / \mathrm{kg})$

$\mathrm{Kp}=$ Keuntungan pemasaran $(\mathrm{Rp} / \mathrm{kg})$

\section{Analisis skala likert}

Indikator aliran produk, keuangan dan informasi kemudian dianalisis menggunakan skala likert. Skala ini terdiri dari beberapa item atau indikator yakni 10 indikator untuk mengukur kelancaran aliran produk cabai, sedangkan pada analisis aliran uang digunakan 9 indikator dan analisis aliran informasi digunakan 14 indikator. Setiap indikator pada masing-masing aliran rantai nilai dinilai dengan menggunakan skala likert dengan nilai 1 (sangat tidak setuju), 2 (tidak setuju), 3 (ragu-ragu), 4 (setuju), dan 5 (sangat setuju). Setelah nilai dari skala likert diperoleh, maka nilai masingmasing indikator pada tiap aliran perlu diuji dahulu validitas dan reabilitasnya.

\section{Strategi penyelesaian masalah}

Untuk menyusun strategi mengatasi masalah pada rantai nilai cabai rawit maka harus mengetahui faktor internal (kekuatan dan kelemahan) ataupun faktor eksternal (peluang dan ancaman) dari usahatani dan pemasaran cabai. Setiap faktor tersebut memiliki indikator yang akan dinilai menggunakan skala likert. Faktor kekuatan terdiri dari 9 indikator, faktor kelemahan terdiri dari 4 indikator sedangkan faktor peluang dan ancaman masing-masing terdapat 6 indikator. Nilai dari setiap indikator merupakan nilai rating yang digunakan untuk analisis SWOT. Nilai likert yang digunakan sebagai nilai rating pada masing-masing indikator tersebut diperoleh melalui wawancara langsung dengan pelaku yang terlibat dalam kegiatan usahatani cabai di Lereng Gunung Merapi. Selain data rating yang diperoleh dari pelaku usahatani, maka perlu ditentukan pula bobot dari masing-masing indikator pada setiap faktor (kekuatan, kelemahan, peluang, dan ancaman) yang berasal dari pemangku kebijakan (stakeholder) dalam usahatani cabai. Rating dan bobot yang sudah diperoleh selanjutnya digunakan untuk menghitung total skor dari masing-masing indikator pada masing-masing faktor yang telah ditentukan.

\section{HASIL DAN PEMBAHASAN}

\section{Aliran Produk}

Rantai nilai cabai di lereng Gunung Merapai dimulai dari petani yang membudidayakan cabai dengan memanfaatkan potensi alam serta menggunakan sarana produksi pertanian secara optimal. Hasil dari proses tersebut adalah cabai rawit segar yang kemudian dijual petani kepada pelaku pemasaran. Berdasarkan hasil analisis, lembaga pemasaran yang terlibat dalam pemasaran cabai di lereng Gunung Merapi meliputi: petani, pedagang pengepul, dan pedagang pengecer.

\section{Petani}

Petani akan menentukan ke mana hasil panen cabai dijual. Dalam proses penjualan, petani bisa membawa hasil panen ke tempat pedagang pengepul atau menghubungi pedagang untuk mengambil cabai yang sudah dipanen. Petani cabai melaksanakan fungsi pertukaran dengan memindahkan kepemilikan 
komoditas cabai ke pedagang melalui proses penjualan. Sebelum melakukan proses penjualan, petani melakukan fungsi fisik yaitu sortasi.

\section{Pedagang pengepul}

Dalam transaksi jual beli, pedagang pengepul memiliki pengaruh lebih besar dalam penentuan harga sehingga petani hanya menerima harga (price taker) yang ditetapkan pedagang. Pedagang pengepul melakukan 3 fungsi pemasaran yaitu pertukaran, fisik, dan fasilitasi. Pedagang pengepul melaksanakan fungsi pertukaran antara lain penjualan dan pembelian. Pedagang pengepul membeli cabai dari petani kemudian menjual ke pedagang pengecer. Pada proses penjualan cabai ke lembaga pemasaran lain, pedagang pengepul juga melakukan fungsi fisik awal yaitu sortasi dan grading. Kemudian pedagang pengepul akan mengirimkan cabai ke pedagang pengecer. Selama proses ini, terjadi risiko kerusakan produk yang ditanggung pedagang pengepul. Selain itu, pedagang pengepul juga menjalankan fungsi lain dengan mengumpulkan informasi pasar mengenai harga yang berlaku (fungsi fasilitasi).

\section{Pedagang pengecer}

Pedagang pengecer memasarkan cabai melalui pasar tradisional di wilayah DIY. Pedagang pengecer melakukan pembayaran secara tunai ketika membeli cabai dari pedagang pengepul dan menerima pembayaran secara tunai pula saat menjual cabai ke konsumen. Fungsi fisik yang dijalankan pedagang pengecer meliputi pengangkutan dan penyimpanan. Fungsi penyimpanan juga dilakukan oleh pedagang pengecer karena pedagang harus menyimpan cabai yang belum terjual. Sedangkan fungsi fasilitasi yang dilakukan oleh pedagang pengecer sama seperti pada pedagang pengepul yakni mengumpulkan informasi harga.

Para pelaku aliran pasok membentuk beberapa saluran pemasaran dalam rangka menyampaikan barang dari produsen sampai dengan konsumen. Dari hasil penelitian dapat disimpulkan saluran pemasaran yang terbentuk meliputi dua jenis.

\section{Saluran pemasaran I}

Pada saluran pemasaran ini, petani memilih untuk menjual cabai langsung ke pedagang pengecer. Pedagang pengecer kemudian menjual kembali cabai yang sudah dibeli dari petani ke konsumen tingkat akhir. Biasanya pedagang pengecer ini berjualan di pasar tradisional sekitar DIY dan menjual cabai langsung ke konsumen. Persentase total produk yang mengalir dalam saluran pemasaran ini sebesar $49,85 \%$. Petani tidak perlu mengeluarkan biaya pengiriman cabai karena pedagang akan mengambil hasil panen cabai ke petani. Cabai yang dibeli pedagang tersebut akan dijual kembali ke konsumen akhir.

\section{Saluran pemasaran II}

Pada saluran pemasaran ini, petani memilih untuk menjual cabai ke pedagang pengepul. Pedagang pengepul kemudian menjual kembali cabai yang sudah dibeli dari petani ke pedagang pengecer. Kemudian cabai yang sudah dibeli pedagang pengecer dijual kembali kepada konsumen tingkat akhir. Pedagang pengecer biasanya menjual cabai ke konsumen akhir melalui pasar tradisional di wilayah DIY antara lain Pasar Giwangan, Pasar Pakem, Pasar Tempel serta Pasar Colombo serta pasar di luar DIY. Dari seluruh saluran pemasaran yang terbentuk di lereng Gunung Merapi, saluran pemasaran jenis ini merupakan pilihan $50,15 \%$ petani. Angka ini menunjukkan saluran ini merupakan saluran pemasaran dengan aliran produk cabai paling dominan. Selain melihat saluran pemasaran, aliran produk cabai pada penelitian ini juga dinilai menggunakan sepuluh indikator (Tabel 1).

Apabila memperhatikan hasil total skor dan kategori yang ada pada setiap indikator aliran produk, maka dapat disimpulkan bahwa komoditas cabai di lereng Gunung Merapi memiliki aliran produk yang lancar (Tabel 1). Indikasi ini menunjukkan secara fisik, cabai hasil produksi petani telah sesuai standar yang diinginkan konsumen. Hal ini sangat penting karena keputusan konsumen membeli cabai merah dipengaruhi keadaan produk, seperti penampakan luar, warna, tidak ada tanda busuk, kebersihan, harga, dan kesegaran cabai (Adiyoga, 2011). Petani dan pedagang melaksanakan fungsi sortasi dan grading dengan cukup ketat sehingga cabai yang dijual memiliki penampilan terbaik. Fungsi transportasi juga berjalan lancar karena ketersediaan alat transportasi (motor, mobil atau truk) yang dimiliki petani maupun pedagang. Hanya satu indikator saja yang termasuk cukup lancar, yaitu jumlah cabai yang dijual. Hal ini terjadi karena kuantitas hasil panen cabai di lereng Gunung Merapi mengalami fluktuasi dan belum mampu memenuhi permintaan konsumen. Fluktuasi ini disebabkan kondisi cuaca yang tidak menentu sehingga berakibat serangan organisme dan pengganggu tanaman (OPT) cukup tinggi. Untuk itu, diperlukan kerjasama antara petani dengan dinas maupun perguruan tinggi dalam pengendalian OPT, baik itu dengan cara alami (misal penggunaan jamur mikoriza arbuskuler) atau cara kimia (Paramita dkk., 2014; Imron dkk., 2015). 
Tabel 1. Indikator aliran produk cabai di lereng Gunung Merapi

\begin{tabular}{clccccl}
\hline No & \multicolumn{1}{c}{ Pertanyaan } & Interval & Skor & Sig Validitas & Total Skor & Kategori \\
\hline 1 & Jumlah yang dijual & $0-4$ & 1,80 & $0,000^{* * *}$ & 72 & Cukup lancar \\
2 & Penimbangan & $0-3$ & 2,00 & $0,000^{* * *}$ & 80 & Lancar \\
3 & Ukuran & $0-5$ & 4,20 & $0,000^{* * *}$ & 168 & Sangat lancar \\
4 & Bentuk & $0-5$ & 4,13 & $0,001^{* * *}$ & 165 & Sangat lancar \\
5 & Warna & $0-5$ & 3,73 & $0,000^{* * *}$ & 149 & Lancar \\
6 & Kebersihan & $0-5$ & 3,75 & $0,000^{* * *}$ & 150 & Lancar \\
7 & Kesegaran & $0-5$ & 3,73 & $0,000^{* * *}$ & 149 & Lancar \\
8 & Kemasan & $0-5$ & 3,98 & $0,002^{* * *}$ & 159 & Lancar \\
9 & Sortasi & $0-5$ & 3,90 & $0,005^{* * *}$ & 156 & Lancar \\
10 & Ketersediaan alat transportasi & $0-5$ & 3,95 & $0,000^{* * *}$ & 158 & Lancar \\
\hline
\end{tabular}

Sumber: Analisis Data Primer (2017)

\section{Aliran Uang}

Salah satu indikator aliran uang adalah marjin pemasaran atau perbedaan harga yang diterima oleh konsumen akhir dengan harga yang diterima petani sebagai produsen. Selisih harga tersebut merupakan biaya dan keuntungan dari para pelaku pemasaran. Dalam suatu saluran pemasaran, diharapkan marjin pemasaran dapat memberikan keuntungan yang proporsional bagi lembaga pemasaran yang terlibat sesuai dengan biaya, risiko, pengorbanan, dan pelayanan yang ditanggung. Marjin dari saluran pemasaran cabai di Lereng Gunung Merapi tersaji pada Tabel 2 dan Tabel 3.

Saluran pertama melibatkan satu lembaga pemasaran yaitu pedagang pengecer sehingga didapatkan marjin pemasaran sebesar Rp3.295,00 per kg cabai (Tabel 2). Hasil analisis ini juga menunjukkan bahwa pedagang memiliki keuntungan cukup besar dan cenderung sebagai penentu harga (price maker).

Tabel 2. Marjin pemasaran cabai pada saluran I di lereng Gunung Merapi

\begin{tabular}{lccc}
\hline \multicolumn{1}{c}{ Lembaga pemasaran } & $\begin{array}{c}\text { Harga } \\
(\mathrm{Rp} / \mathrm{kg})\end{array}$ & $\begin{array}{c}\text { Biaya } \\
(\mathrm{Rp} / \mathrm{kg})\end{array}$ & $\begin{array}{c}\text { Marjin } \\
(\mathrm{Rp} / \mathrm{kg})\end{array}$ \\
\hline Petani & & - & \\
$\begin{array}{l}\text { a. Harga produksi } \\
\text { b. Biaya }\end{array} \quad 17.552$ & - & 173 & - \\
$\quad$ Total harga jual & 17.725 & - & \\
Pedagang pengecer & & & \\
$\begin{array}{l}\text { a. Harga beli } \\
\text { b. Biaya }\end{array}$ & 17.725 & - & \\
C. Harga jual & - & 789 & 3.295 \\
$\quad$ Keuntungan & 21.020 & - & \\
\hline
\end{tabular}

Sumber: Analisis data primer tahun 2017
Kondisi ini tidak ideal dalam perdagangan komoditas pertanian karena menyebabkan harga yang diterima petani cukup rendah sedangkan harga konsumen cukup tinggi.

Pada saluran pemasaran kedua, terdapat dua lembaga pemasaran yang terlibat yaitu pedagang pengepul dan pedagang pengecer (Tabel 3 ). Keuntungan yang diterima pedagang pengepul sebesar Rp1.543,00 per kilogram dan keuntungan yang diperoleh pedagang pengecer sebesar Rp1.523,00 per kilogram dengan total marjin pemasaran sebesar Rp4.600,00. Hasil ini sebenarnya memilki kemiripan dengan saluran sebelumnya dimana peran pedagang cukup dominan dalam penentuan harga sehingga keuntungan yang diperoleh pedagang sangat besar.

Berdasarkan hasil analisis dapat diketahui besarnya marjin pemasaran semakin meningkat seiring dengan semakin panjang saluran pemasaran yang terbentuk. Hal ini dipengaruhi oleh semakin banyaknya lembaga pemasaran yang terlibat dalam saluran pemasaran tersebut. Ciri khas komoditas pertanian ini sesuai dengan penelitian Baihaqi dkk. (2014) yang menemukan aliran produk dari petani ke pembeli akhir akan mengubah nilai dari produk tersebut. Perubahan ini terjadi akibat adanya penanganan pasca panen dan proses pemasaran. Hal serupa juga terjadi pada pemasaran cabai di Lereng Gunung Merapi yang mengalami perubahan nilai karena biaya transportasi, sortasi dan grading serta pengepakan yang dikeluarkan pelaku pemasaran.

Hasil nilai marjin juga mampu digunakan untuk mengetahui efisiensi saluran pemasaran dimana semakin tinggi nilai marjin maka pemasaran semakin tidak efisien. Dari kedua saluran pemasaran yang ada, saluran pertama adalah yang paling efisien. Setelah melakukan analisis marjin pemasaran, analisis lanjutan 
Tabel 3. Marjin pemasaran cabai pada saluran pemasaran II di lereng Gunung Merapi

\begin{tabular}{|c|c|c|c|}
\hline Lembaga pemasaran & $\begin{array}{l}\text { Harga } \\
\text { (Rp/kg) }\end{array}$ & $\begin{array}{c}\text { Biaya } \\
\text { (Rp/kg) }\end{array}$ & Marjin \\
\hline \multicolumn{4}{|l|}{ Petani } \\
\hline a. Harga & 21.027 & - & \\
\hline b. Biaya & - & 173 & - \\
\hline Total harga jual & 21.200 & - & \\
\hline \multicolumn{4}{|l|}{ Pedagang pengepul } \\
\hline a. Harga beli & 21.200 & - & \\
\hline b. Biaya & - & 1.057 & 2.600 \\
\hline c. Harga jual & 23.800 & - & \\
\hline Keuntungan & \multicolumn{2}{|c|}{1.543} & \\
\hline \multicolumn{4}{|l|}{ Pedagang pengecer } \\
\hline a. Harga beli & 23.800 & - & \\
\hline b. Biaya & - & 477 & 2.000 \\
\hline c. Harga jual & 25.800 & & \\
\hline Keuntungan & \multicolumn{2}{|c|}{1.523} & \\
\hline Total marjin & & & \\
\hline
\end{tabular}

Sumber: Analisis data primer tahun 2017

mengenai aliran uang pada rantai nilai komoditas cabai di Lereng Gunung Merapi dapat dilakukan dengan menggunakan sembilan indikator (Tabel 4).

Indikator aliran uang komoditas cabai di Lereng Gunung Merapi sebagian besar sangat lancar karena tempat transaksi antar pelaku pemasaran yang berdekatan dengan sistem transaki jual-beli tunai saat produk berpindah tangan (Tabel 4). Pelaku pemasaran juga tidak mengalami kesulitasn dalam pembayaran biaya kredit atau lainnya karena memperoleh keuntungan besar dari jual beli cabai. Masalah utama dalam aliran keuangan adalah petani kesulitan untuk mengakses kredit dari perbankan. Petani lebih cenderung meminjam dana dari perorangan karena kemudahan proses transkasi.

\section{Aliran Informasi}

Selain aliran produk dan aliran uang, rantai nilai komoditas cabai di Lereng Gunung Merapi juga dapat dinilai menurut aliran informasi yang bergerak dalam rantai tersebut (Tabel 5).

Secara umum, aliran informasi telah berlangsung lancar, walaupun ada juga yang termasuk cukup lancar. Petani memperoleh informasi varietas cabai yang akan ditanam dari sales perusahaan benih. Untuk menentukan musim tanam dan musim panen, petani biasanya menggunakan pengalaman sebelumnya. Informasi harga juga sangat mudah diperoleh pelaku pemasaran karena sistem harga yang relatif terbuka antar pelaku pemasaran, walaupun pada kenyataannya petani sering memperoleh harga di bawah ekspektasi. Namun begitu, pelaku pemasaran sulit untuk memperoleh informasi mengenai jumlah permintaan dan penawaran cabai di pasaran. Pedagang kesulitan untuk mengetahui jumlah penawaran (kuantitas produksi) komoditas cabai sedangkan petani kesulitan memperoleh informasi permintaan. Informasi mengenai persaingan antar pelaku juga cukup sulit ditentukan, karena hampir seluruh lembaga memiliki pangsa pasarnya masingmasing.

Seluruh indikator pada masing-masing aliran dapat dilakukan skoring secara menyeluruh di setiap aliran tersebut untuk mengetahui kelancaran total pada setiap aliran rantai nilai (Tabel 6).

Tabel 4. Indikator aliran uang komoditas cabai di lereng Gunung Merapi

\begin{tabular}{llccccl}
\hline No & \multicolumn{1}{c}{ Pertanyaan } & Interval & Skor & $\begin{array}{c}\text { Sig } \\
\text { Validitas }\end{array}$ & Total Skor & Kategori \\
\hline 1 & Tempat transaksi & $0-5$ & 3,75 & $0,000^{* * *}$ & 150 & Lancar \\
2 & Cara transaksi & $0-4$ & 3,53 & $0,011^{* * *}$ & 141 & Sangat lancar \\
3 & Cara pembayaran transaksi & $0-4$ & 3,48 & $0,007^{* * *}$ & 139 & Sangat lancar \\
4 & Waktu pembayaran transaksi & $0-5$ & 4,03 & $0,000^{* * *}$ & 161 & Sangat lancar \\
5 & Cara memperoleh modal & $0-5$ & 4,00 & $0,000^{* * *}$ & 160 & Lancar \\
6 & Cara pembayaran kredit & $0-4$ & 3,55 & $0,001^{* * *}$ & 142 & Sangat lancar \\
7 & Waktu pembayaran kredit & $0-4$ & 3,60 & $0,001^{* * *}$ & 144 & Sangat lancar \\
8 & Pembayaran retribusi & $0-4$ & 3,70 & $0,000^{* * *}$ & 148 & Sangat lancar \\
9 & Pembayaran uang keamanan di pasar & $0-4$ & 3,78 & $0,001^{* * *}$ & 151 & Sangat lancar \\
\hline
\end{tabular}

Keterangan: ${ }^{* * *}$ signifikan pada tingkat kepercayaan $95 \%$

Sumber: analisis data primer (2017) 
Secara keseluruhan, aliran rantai nilai komoditas cabai di Lereng Gunung Merapi termasuk dalam kategori lancar. Aliran uang pada rantai nilai komoditas cabai di Lereng Gunung Merapi memiliki kategori yang terbaik, yaitu kategori sangat lancar. Aliran produk dan informasi yang terjadi pada sistem rantai nilai cabai di Lereng Gunung Merapi secara menyeluruh juga termasuk dalam kategori lancar. Hal ini menunjukkan sistem tata

Tabel 5. Indikator aliran informasi komoditas cabai di lereng Gunung Merapi

\begin{tabular}{clccccc}
\hline No & \multicolumn{1}{c}{ Pertanyaan } & Interval & Skor & $\begin{array}{c}\text { Sig } \\
\text { Validitas }\end{array}$ & $\begin{array}{c}\text { Total } \\
\text { Skor }\end{array}$ & Kategori \\
\hline 1 & Jenis varietas yang ditanam & $0-3$ & 1,98 & $0,004^{* * *}$ & 79 & Lancar \\
2 & Musim tanam & $0-3$ & 2,00 & $0,000^{* * *}$ & 80 & Lancar \\
3 & Musim panen & $0-4$ & 2,05 & $0,000^{* * *}$ & 82 & Cukup lancar \\
4 & Penawaran/produksi & $0-3$ & 1,58 & $0,000^{* * *}$ & 63 & Cukup lancar \\
5 & Permintaan/pesanan & $0-3$ & 1,68 & $0,001^{* * *}$ & 67 & Cukup lancar \\
6 & Penanganan pasca panen & $0-3$ & 2,10 & $0,000^{* * *}$ & 84 & Lancar \\
7 & Harga beli & $0-5$ & 3,85 & $0,007^{* * *}$ & 154 & Lancar \\
8 & Harga jual & $0-5$ & 3,70 & $0,008^{* * *}$ & 148 & Lancar \\
9 & Mutu atau kualitas & $0-3$ & 2,20 & $0,000^{* * *}$ & 88 & Lancar \\
10 & Waktu kirim & $0-3$ & 2,15 & $0,000^{* * *}$ & 86 & Lancar \\
11 & Modal transportasi & $0-3$ & 2,23 & $0,000^{* * *}$ & 89 & Lancar \\
12 & Jarak dan alamat tujuan & $0-3$ & 2,23 & $0,000^{* * *}$ & 89 & Lancar \\
13 & Persaingan antar pelaku & $0-3$ & 1,65 & $0,000^{* * *}$ & 66 & Cukup lancar \\
14 & Preferensi pedagang pengecer & $0-3$ & 2,13 & $0,000^{* * *}$ & 85 & Lancar \\
\hline
\end{tabular}

Keterangan: ${ }^{* * *}$ signifikan pada tingkat kepercayaan $95 \%$

Sumber: Analisis data primer (2017)

Tabel 6. Skoring total indikator aliran produk, aliran uang, dan aliran informasi komoditas cabai di lereng Gunung Merapi

\begin{tabular}{|c|c|c|c|c|c|}
\hline No. & Menurut aliran & Interval skor & Kategori & Skor & Tergolong kategori \\
\hline \multirow{5}{*}{1} & \multirow{5}{*}{ Aliran produk } & $0-376$ & Tidak lancar & \multirow{5}{*}{1406} & \multirow{5}{*}{ Lancar } \\
\hline & & $377-752$ & Kurang lancar & & \\
\hline & & $753-1128$ & Cukup lancar & & \\
\hline & & $1129-1504$ & Lancar & & \\
\hline & & $1505-1880$ & Sangat lancar & & \\
\hline \multirow{5}{*}{2} & \multirow{5}{*}{ Aliran uang } & $0-312$ & Tidak lancar & \multirow{5}{*}{1336} & \multirow{5}{*}{ Sangat lancar } \\
\hline & & $313-624$ & Kurang lancar & & \\
\hline & & $625-936$ & Cukup lancar & & \\
\hline & & $937-1248$ & Lancar & & \\
\hline & & $1249-1560$ & Sangat lancar & & \\
\hline \multirow{6}{*}{3} & \multirow{5}{*}{ Aliran informasi } & $0-376$ & Tidak lancar & \multirow{5}{*}{1260} & \multirow{5}{*}{ Lancar } \\
\hline & & $377-752$ & Kurang lancar & & \\
\hline & & $753-1128$ & Cukup lancar & & \\
\hline & & $1129-1504$ & Lancar & & \\
\hline & & $1505-1880$ & Sangat lancar & & \\
\hline & Kesimpulan & & & & Lancar \\
\hline
\end{tabular}

Sumber: Analisis data primer (2017) 
Tabel 7. Total skor indikator-indikator kekuatan, kelemahan, peluang, dan ancaman usahatani cabai di lereng Gunung Merapi

\begin{tabular}{|c|c|c|c|c|}
\hline No. & Faktor internal & Rating & Bobot & Bobot skor \\
\hline \multicolumn{5}{|c|}{ Kekuatan (Strengeth) } \\
\hline 1 & Banyak petani cabai berusia produktif. & 2 & 14,93 & 31,34 \\
\hline 2 & Petani memiliki cukup pengalaman budidaya cabai. & 2 & 11,94 & 25,47 \\
\hline 3 & Petani memiliki keterampilan budidaya cabai. & 2 & 10,45 & 22,99 \\
\hline 4 & Lokasi lahan dekat dengan jalan utama. & 4 & 10,45 & 43,53 \\
\hline 5 & Kemudahan akses memperoleh input pertanian. & 4 & 13,43 & 53,73 \\
\hline 6 & Peralatan budidaya lengkap dan memadai. & 4 & 13,43 & 56,42 \\
\hline 7 & Kemudahan mendapat akses permodalan & 4 & 11,94 & 47,36 \\
\hline 8 & Kemudahan dalam menjual hasil panen cabai. & 4 & 13,43 & 48,36 \\
\hline & Total skor kekuatan & 26 & 100,00 & 329,20 \\
\hline \multicolumn{5}{|c|}{ Kelemahan (weakness) } \\
\hline 1 & Produksi cabai relatif rendah. & 4 & 25,93 & 105,43 \\
\hline 2 & Kemampuan petani yang terbatas dalam penyimpanan produk. & 1 & 22,22 & 28,89 \\
\hline 3 & Penerapan GAP dan SOP yang belum berjalan. & 1 & 18,52 & 24,07 \\
\hline 4 & Petani kurang memahami informasi pasar. & 2 & 33,33 & 60,00 \\
\hline & Total skor kelemahan & 8 & 100,00 & 218,40 \\
\hline & Selisih kekuatan-kelemahan & & & 110,81 \\
\hline No & Faktor eksternal & Rating & Bobot & Bobot skor \\
\hline \multicolumn{5}{|c|}{ Peluang (opportunity) } \\
\hline 1 & Harga tawar cabai yang tinggi. & 4 & 18,75 & 65,63 \\
\hline 2 & Bantuan modal dan peralatan dari Pemerintah. & 2 & 20,83 & 34,03 \\
\hline 3 & $\begin{array}{l}\text { Permintaan cabai meningkat seiring dengan meningkatnya pertumbuhan } \\
\text { penduduk. }\end{array}$ & 2 & 20,83 & 43,75 \\
\hline 4 & $\begin{array}{l}\text { Kebijakan Pemerintah "Gerakan Nasional Penanaman } 50 \text { uta Pohon Cabai" } \\
\text { dapat menekan inflasi harga cabai. }\end{array}$ & 1 & 14,58 & 21,39 \\
\hline 5 & $\begin{array}{l}\text { Himbauan Pemerintah mengenai tanam serempak dan pengaturan pola } \\
\text { tanam untukmenstabilkan harga. }\end{array}$ & 2 & 12,50 & 20,00 \\
\hline 6 & $\begin{array}{l}\text { Kebijakan Pemerintah mengenai "Harga Referensi" untuk menjaga stabilisasi } \\
\text { pasokan dan harga produk hortikultura khususnya cabai. }\end{array}$ & 4 & 12,50 & 49,17 \\
\hline & Total skor peluang & 14 & 100,00 & 233,96 \\
\hline \multicolumn{5}{|c|}{ Ancaman (threat) } \\
\hline 1 & Faktor curah hujan tinggi dapat merusak hasil panen cabai. & 4 & 19,05 & 71,11 \\
\hline 3 & Adanya fluktuasi harga cabai. & 4 & 19,05 & 69,84 \\
\hline 4 & Pembagian marjin rantai nilai yang timpang antara petani dan pedagang. & 2 & 16,67 & 26,67 \\
\hline 5 & Panjangnya rantai pemasaran cabai. & 2 & 21,43 & 48,57 \\
\hline 6 & Adanya kebijakan impor cabai. & 1 & 23,81 & 23,02 \\
\hline \multicolumn{2}{|r|}{ Total skor ancaman } & 12 & 100,00 & 239,21 \\
\hline \multicolumn{2}{|r|}{ Selisih peluang-ancaman } & & & $-5,25$ \\
\hline
\end{tabular}

Sumber: Analisis data primer (2017) 
niaga tidak mengalami hambatan, sehingga komoditas cabai di Lereng Gunung Merapi memiliki potensi yang baik untuk dikembangkan.

\section{Strategi Manajemen Komoditas Cabai di Lereng Gunung Merapi}

Pengembangan komoditas cabai perlu memperhatikan faktor internal dan faktor eksternal yang mempengaruhi, sehingga dapat dirumuskan kebijakan yang sesuai dengan kondisi lapangan (Tabel 7).

Kekuatan terbesar yang ada dalam usahatani cabai di Lereng Gunung Merapi adalah peralatan budidaya cabai yang lengkap dan memadai sedangkan nilai terkecil adalah keterampilan budidaya. Petani selama ini kurang aktif berpartisipasi dalam kegiatan penyuluhan dan pelatihan sehingga tidak memperoleh teknologi budidaya terbaru. Pada faktor kelemahan, indikator yang memiliki nilai skor terbesar adalah produksi cabai relatif rendah. Hal ini terjadi karena perubahan kondisi alam yang menyebabkan peningkatan serangan organisme pengganggu tanaman.

Pada faktor eksternal, yaitu peluang menjalankan usahatani cabai menunjukkan indikator yang memiliki nilai bobot skor tertinggi adalah indikator harga tawar cabai yang tinggi. Kondisi ini memang terjadi di Indonesia dalam beberapa tahun terakhir dimana harga cabai sangat tinggi pada waktu tertentu. Nilai terendah pada faktor peluang adalah kebijakan pemerintah tentang penanaman 50 juta pohon cabai. Kebijakan ini tidak diketahui oleh petani serta tidak ada langkah nyata dari pemerintah terkait program ini, seperti pembagian sarana produksi pertanian, sehingga dampak kebijakan ini tidak dirasakan petani. Ancaman terbesar bagi perkembangan usahatani cabai di lereng Gunung Merapi adalah faktor cuaca, yaitu curah hujan tinggi yang menyebabkan serangan hama dan penyakit tumbuhan bagi tanaman cabai, sehingga merusak tanaman dan menimbulkan kerugian yang besar bagi petani. Selain itu, fluktuasi harga cabai juga menjadi ancaman karena terkadang petani harus menerima harga cabai rendah sehingga menyebabkan petani mengalami kerugian.

Berdasarkan hasil analisis rantai nilai cabai di lereng Gunung Merapi, maka strategi yang ideal bagi pengembangannya adalah ST (Gambar 2). Strategi tersebut muncul karena kekuatan pasar lelang yang lebih besar daripada kelemahannya $(+110,81)$ dan ancamana lebih besar daripada peluang yang dihadapinya $(-5,25)$. Secara operasional, stakeholder's perlu melakukan beberapa hal yaitu: penyuluhan dan pelatihan budidaya cabai yang intensif dan dari dinas; penanganan pasca panen di tingkat petani secara profesional; dan penguatan pasar lelang cabai di Kabupaten Sleman.

\section{Penyuluhan dan pelatihan budidaya cabai yang intensif dari dinas}

Pemerintah melalui penyuluh lapangan perlu secara intensif mengadakan penyuluhan mengenai budidaya cabai mengingat komodtas ini sangat rentan terhadap perubahan kondisi lingkungan. Selama ini penyuluhan yang diperoleh petani berasal dari perusahaan penghasil benih ataupun penghasil pestisida sehingga memiliki motif kepentingan ekonomi perusahaan yang lebih kuat daripada motif pendidikan bagi petani. Hal ini menyebabkan petani berpola pikir instan dalam

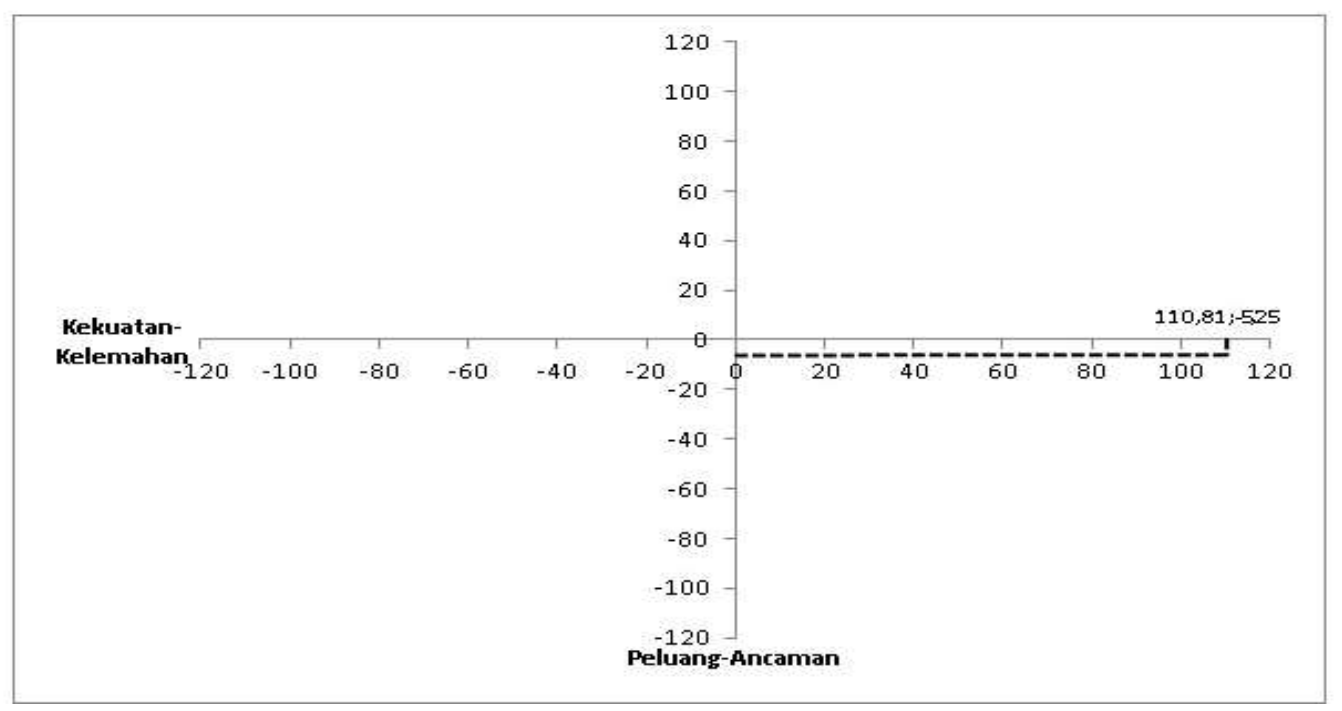

Gambar 2. Posisi matrik SWOT usahatani cabai di lereng Gunung Merapi

Sumber: Analisis Data Primer (2017) 
budidaya cabai seperti pengendalian hama dengan pestisida kimia tanpa mempertimbangkan aturan pakai produk tersebut. Selain itu, penyuluhan seharusnya diutamakan terkait pengaturan pola tanam cabai yang disesuaikan dengan kondisi agroklimat. Pengaturan pola tanam yang tepat dapat mengurangi dampak serangan hama dan penyakit cabai. Selain itu, pengaturan pola tanam yang baik dapat menstabilkan harga jual cabai di tingkat petani. Penyuluhan juga terkait dengan cara pengendalian organisme pengganggu tanaman baik itu secara alami maupun buatan, seperti penggunaan rumah kasa, mulsa plastik, varietas unggul maupun pestisida (Prabaningrum dan Moekasan, 2014).

\section{Penanganan pasca panen di tingkat petani secara profesional}

Ancaman terbesar yang dihadapi petani di Lereng Gunung Merapi adalah produk yang mudah rusak. Produksi cabai umumnya langsung dijual dalam kondisi segar oleh petani. Hal ini memberikan dampak harga jual yang diterima petani akan terpengaruh fluktuasi harga cabai setiap waktu. Untuk mengurangi dampak fluktuasi harga cabai yang tinggi, maka diperlukan sistem penyimpanan yang baik sehingga petani dapat menerapkan sistem tunda jual. Sistem penyimpanan yang dapat dilakukan dengan menggunakan teknologi cold-storage. Cabai segar dapat disimpan pada coldstorage jika kondisi harga rendah dan menjualnya ketika harga naik. Penanganan pasca panen selanjutnya dapat dilakukan melalui aktivitas diversifikasi produk cabai segar menjadi berbagai olahan lain yang menguntungkan dan strategis. Penelitian Priantara dkk (2016) menunjukkan kegiatan pasca panen komoditas pertanian pada dasarnya mampu menghasilkan nilai tambah bagi petani bahkan pada rasio nilai tambah tinggi di atas $40 \%$.

\section{Penguatan pasar lelang cabai di Kabupaten Sleman}

Ancaman selanjutnya bagi petani adalah terjadinya fluktuasi harga yang tinggi saat hendak menjual hasil panenannya. Harga yang ditawarkan sering kali jauh lebih rendah dari harga pasar yang terbentuk. Fluktuasi harga sayuran dan buah yang relatif tinggi membuka peluang bagi pedagang sayuran dan buah untuk memanipulasi informasi harga dan menekan harga di tingkat petani (Irawan dan Ariningsih, 2014). Rendahnya posisi tawar petani dalam memasarkan produksi cabai menyebabkan hal ini dapat terjadi.

Untuk mengatasinya diperlukan suatu lembaga yang dapat memfasilitasi petani dan lembaga pemasaran lainnya agar dapat saling bertemu dan berkompetisi dalam menjual dan membeli produk cabai yang terbaik. Lembaga yang paling ideal untuk mengatasi masalah tersebut adalah pasar lelang. Pasar lelang memiliki fungsi mempertemukan pedagang sebagai pembeli dan petani atau kelompok tani sebagai pemiliki komoditas yang akan diperjualbelikan. Pembentukan pasar lelang diharapkan memperkuat posisi tawar petani untuk memperoleh harga yang kompetitif dari pedagang serta mengurangi tingginya marjin pemasaran. Hasil penelitian Devi dkk (2015) menunjukkan pasar lelang cabai merah di Kulon Progo efektif untuk meningkatkan pendapatan petani karena harga jual cabai menjadi lebih tinggi.

Pasar lelang juga dapat menjadi salah satu solusi untuk mengatasi tantangan yang dihadapi agribisnis sayuran di Indonesia yakni mendorong sistem logistik yang efisien dan mampu mengendalikan pasokan produk secara tepat waktu, tepat kualitas dan kuantitas yang dibutuhkan pasar dengan biaya murah (Irawan dan Ariningsih, 2014). Hal yang paling penting dari lembaga ini adalah mampu menjamin terjualnya produk dalam jumlah besar dengan harga yang menguntungkan bagi petani dan pedagang (Prabhavathi dkk., 2013). Dengan begitu, Pemkab Sleman perlu untuk memperkuat pasar lelang cabai yang telah ada di wilayahnya.

\section{KESIMPULAN}

Pelaku aktivitas rantai nilai cabai yakni petani, pedagang pengepul, pedagang pengecer dan konsumen dengan saluran pemasaran paling efisien saat petani menjual cabai kepada pedagang pengecer dan kemudian pedagang tersebut menjual ke konsumen. Secara keseluruhan aliran rantai nilai komoditas cabai di Lereng Gunung Merapi termasuk dalam kategori lancar. Aliran uang memiliki kategori sangat lancar karena penampilan cabai telah melalui proses sortasi dan grading ketat serta sesuai keinginan konsumen sedangkan aliran produk termasuk kategori lancar karena sistem pembayaran antar pelaku bisnis yang saling menguntungkan dan aliran informasi juga termasuk lancar karena kemudahan akses informasi antar pelaku rantai nilai cabai. Hal ini menunjukkan sistem tata niaga cabai relatif tidak memiliki hambatan. Namun begitu masih terdapat beberapa masalah diantaranya kemampuan budidaya petani masih rendah, fluktuasi produksi dan harga cabai. Untuk mengatasi masalah yang ada diperlukan penyuluhan dan pelatihan budidaya cabai yang intensif dari dinas, penanganan pasca panen di tingkat petani secara profesional dan penguatan pasar lelang cabai di Kabupaten Sleman. 


\section{UCAPAN TERIMA KASIH}

Penulis mengucapkan terima kasih kepada Direktorat Penelitian, Lembaga Penelitian dan Pengabdian kepada Masyarakat (LPPM) Universitas Gadjah Mada yang telah membiayai penelitian ini.

\section{KONFLIK KEPENTINGAN}

Dengan ini penulis menyatakan tidak ada konflik kepentingan (confict of interest) dari berbagai pihak yang dituliskan pada naskah ini.

\section{DAFTAR PUSTAKA}

Adiyoga, W. (2011). Faktor-faktor yang mempengaruhi perilaku dan keputusan konsumen untuk membeli kentang, bawang merah, dan cabai merah. J. Hort, 21(3), 280-294 .http://dx.doi.org/10.21082/jhort. v21n3.2011.p280-294.

Baihaqi, A., Hamid, A. H., Romano, \& Yulianda, A. (2014). Analisis rantai nilai dan nilai tambah kakao petani di Kecamatan Paya Bakong Dan Geurudong Pase Kabupaten Aceh Utara. Agrisep, 15(2), 28-35.

Devi, P., Harsoyo. \& Subejo. (2015). Keefektifan lembaga pasar lelang cabai merah di Kecamatan Panjatan, Kabupaten Kulon Progo. Jurnal Agro Ekonomi, 26(2), 139-149. https://doi.org/10.22146/agroekonomi.17273.

Imron, M., Suryanti, \& Sulandari, S. (2015). Peranan jamur mikoriza arbuskular terhadap perkembangan penyakit daun keriting kuning cabai. Jurnal Perlindungan Tanaman Indonesia, 19(2), 94-98. https://doi.org/10.22146/ jpti. 17251

Irawan, B., \& Ariningsih, E. (2014). Agribisnis Sayuran dan Buah: Peluang Pasar, Dinamika Produksi dan Strategi Peningkatan Daya Saing dalam Memperkuat Daya Saing Produk Pertanian. Jakarta: IAARD Press.

Istiyanti, E. (2010). Efisiensi pemasaran cabai merah keriting di Kecamatan Ngemplak Kabupaten Sleman. Jurnal Pertanian Mapeta, 12(2), 116-124.

Kaplinsky, R. (2013). Global Value Chains, Where They Came From, Where They Are Going and Why This Is Important. London: The Open University.

Kementerian Perdagangan. (2017). Analisis Perkembangan Harga Bahan Pangan Pokok di Pasar Domestik dan Internasional. Jakarta: Pusat Pengkajian Perdagangan Dalam Negeri, Badan Pengkajian dan Pengembangan Perdagangan, Kementerian Perdagangan Republik Indonesia.

Kumar, D., \& Rajeev P. V. (2016). Value chain: a conceptual framework. International Journal of Engineering and Management Science, 7(1), 74-77. Retrieved from:
http://scienceandnature.org/IJEMS-Vol7(1)-Jan2016/ IJEMS Vol7(1)-12.pdf.

Mangifera, L. (2015). Analisis rantai nilai (value chain) pada produk batik tulis di Surakarta. Benefit Jurnal Manajemen dan Bisnis, 19(1), 24-33. https://doi.org/10.23917/ benefit.v1i1.1412.

Paramita, N. K., Sumardiyono, C., \& Sudarmadi. (2014). Pengendalian kimia dan ketahanan Colletotrichum spp. terhadap fungisida simoksanil pada cabai merah. Jurnal Perlindungan Tanaman Indonesia, 18(1), 4146. https://doi.org/10.22146/jpti.15601

Prabaningrum, L., \& Moekasan, T. K. (2014). Pengelolaan organisme pengganggu tumbuhan utama pada budidaya cabai merah di dataran tinggi (pest and disease management on hot pepper cultivation in high land). $J$. Hort, 24(2), 179-188. http://dx.doi.org/10.21082/jhort. v24n2.2014.p179-188.

Prabhavathi, Y., Krishna, N. T., \& Seema, D. (2013). Analysis of supply chain of spices in India: a case study of red chillies. International Journal of Scientific and Research Publications, 3(9), 1-4. Retrieved from http://www.ijsrp. org/research-paper-0913/ijsrp-p21101.pdf.

Priantara, I. D. G. Y., Mulyani, S., \& Satriawan, I. K. (2016). Analisis nilai tambah pengolahan kopi arabika Kintamani Bangli. Jurnal Rekayasa dan Manajemen Agroindustri, 4(4), 33-42.

Rofaida, R. (2012). Analisis dan strategi upgrading rantai nilai (value chain management) pada industri susu di Kabupaten Bandung Barat. Jurnal Riset Manajemen, $1(1), 59-71$.

Rum, M. (2011). Analisis marjin pemasaran dan sensitivitas cabai besar di Kabupaten Malang. Embryo, 8(2), 133141.

Sipayung, F. (2010). Value chain analysis untuk keunggulan kompetitif melalui keunggulan biaya. Jurnal Ekonom, 13(1), 36-44.

Timisela, N. R., Masyhuri, Darwanto, D. H., \& Hartono, S. (2014). Manajemen rantai pasok dan kinerja agroindustri pangan lokal sagu di Propinsi Maluku: suatu pendekatan model persamaan struktural. Agritech, 34(2), 184-193.

Tsurayya, S., \& Kartika, L. (2015). Kelembagaan dan strategi peningkatan daya saing komoditas cabai Kabupaten Garut. Jurnal Manajemen dan Agribisnis, 12(1), 1-13. https://doi.org/10.17358/JMA.12.1.1.

Widiastuti, N. U. R., \& Harisudin, M. (2013). Saluran dan marjin pemasaran jagung di Kabupaten Grobogan. SEPA, 9(2), 231-240.

Tubagus, L. S., Mangantar, M., \& Tawas, H. (2016). Analisis rantai pasokan (supply chain) komoditas cabai rawit di Kelurahan Kumelembuai Kota Tomohon. Jurnal EMBA, $4(2), 613-621$. 